\title{
3. Oblivious to the obvious? Australian asylum-seeker policies and the use of the past
}

\author{
Klaus Neumann
}

References to the past play a crucial role in the development of government policy. Those drafting a new policy often try to heed what they consider to be historical lessons. In order to construct such lessons, they might, for example, analyse the effectiveness of analogous previous policies. Contributors to public debates about government policy, be it within or outside the parliamentary arena, also regularly draw on the past in support or criticism of new initiatives. In discussions about new policies, however, relevant pasts tend to be invoked selectively. Occasionally, policy makers or contributors to public debate ignore historical policies and practices. Often they do so because they assume that the situation prompting the formulation of a new policy is unprecedented.

Two instances of a highly selective remembering of precedents and relevant historical contexts are the subject of this chapter. My first case concerns the development of an Australian Government response to the anticipated arrival of Vietnamese 'boat people' in 1975; here, I am particularly concerned with the selective use of the past by policy makers. In the second case-a debate about a bill designed to prevent asylum-seekers from engaging Australia's protection obligations - I am concerned mainly with the public use of the past by supporters and opponents of the proposed legislation.

In the first case, policy makers ignored what appeared to be highly relevant historical precedents in their deliberations. In the second case, contributors to public debate invoked histories that were blatantly inaccurate. It is tempting simply to identify and highlight such omissions and errors in order to draw attention to inadequacies in the process of policy formulation, and to the shortcomings of particular political debates. As satisfying as such an approach might be, however, it would add little to our understanding of the political process. In the following, I demonstrate that the analysis of apparent failures to draw on the past could contribute to a better understanding of the role of histories in policy making and historical debate.

\section{'Boat people' (I)}

On 6 May 1975, a week after the US military had evacuated some 7000 people from Saigon in the course of Operation Frequent Wind, an Australian newspaper 
ran the following headline on its front page: 'Fleeing Vietnamese ships may risk voyage to Australia.' ${ }^{\prime}$ The article referred to the exodus of refugees from southern Vietnam. It reported that 5700 refugees had already arrived in Singapore, where 32 vessels carrying refugees could be counted in the harbour. The Singaporean authorities, however, while willing to provide food, water and medical aid, were adamant that the refugees had to move on. Other South-East Asian nations were equally reluctant to accommodate Vietnamese refugees, including those rescued in the South China Sea by cargo ships. As Singapore, Hong Kong and Thailand were trying to shut their doors to people fleeing Vietnam, other countries in the region became obvious potential destinations. According to the newspaper article, 'there were unconfirmed reports that a tanker with 200 refugees aboard was heading for Australia'. The story was picked up by the Opposition's foreign affairs spokesperson, Andrew Peacock, who echoed the concerns expressed in the article. ${ }^{2}$ That same day, Australia's Foreign Minister, Don Willesee, wrote to Prime Minister, Gough Whitlam:

I am concerned that the question of the Vietnamese refugees in Singapore and the 'spectre of an armada' sailing for Australia will now become the issue which will most attract public opinion and potentially present the greatest problems. ${ }^{3}$

A paper drafted by a Department of Foreign Affairs officer three days later painted a picture that was even more alarming than that depicted in the newspaper. According to information received by the department, one of the ships in Singapore Harbour, which was carrying 'several hundred Vietnamese', intended to proceed to Sydney, while another, with 287 refugees on board, was also headed for Australia. The officer reported that 'the Singaporean authorities have provided the refugee ships with water and charts for Australia', and concluded that 'it is only sensible to assume that some smaller craft will also make the attempt'.

On 19 May 1975, the Department of Labour and Immigration convened an interdepartmental meeting 'to consider contingency planning in case sea craft carrying South Vietnamese...should arrive in Australian waters or make landfall on the Australian coast without approval'. ${ }^{5}$ The meeting was attended by 20 representatives from the Departments of Labour and Immigration, Foreign Affairs, Prime Minister and Cabinet, Health, Police and Customs, Transport, Defence, Northern Territory, Social Security, and Housing and Construction. Its main outcome was the decision that the Departments of Labour and Immigration, Foreign Affairs and Prime Minister and Cabinet jointly draft a paper assessing the situation and exploring options available to the government should the anticipated arrival of Vietnamese refugees eventuate.

The authors of that paper noted Australia's international legal obligations under the UN Convention Relating to the Status of Refugees, the Agreement Relating 
to Refugee Seamen, the Convention for the Safety of Life at Sea, the Declaration on Territorial Asylum and Article 14 of the Universal Declaration of Human Rights ('Everyone has the right to seek and to enjoy in other countries asylum from persecution'). They also outlined two 'political considerations' - namely, that the arrival of a boat carrying Vietnamese refugees could not be kept a secret, and that

[i]t must be expected that if the Australian Government allows people arriving in small boats to land and remain in Australia this would create a precedent which would not go unremarked by people in a number of countries to the north of Australia. Even if it did not lead to an influx of South Vietnamese it could have future implications in the event of internal political or economic crises developing in other countries to our north. ${ }^{6}$

The authors discussed two options: the refugees could be either prevented from landing in Australia (by stopping refugee boats entering Australian territorial waters or by preventing their passengers and crew from disembarking) or allowed to land. They counselled against the first option on account of Australia's international legal obligations and of the anticipated 'weight of public opinion' in favour of Vietnamese refugees, and pointed out that the second option entailed several possibilities: the refugees could be allowed to land without granting them entry permits, they could be issued with limited permits or they could be disembarked 'into custody' in order to be able to return them to their boat 'for the purpose of departing them from Australia'. ${ }^{7}$ The paper did not explore to what extent any of these options was practicable and did not advocate a particular course of action.

On 2 April 1975, Prime Minister Whitlam had assumed responsibility for all issues concerning Vietnamese refugees. He had already overseen two controversial initiatives: the two so-called 'baby lifts' on 5 and 18 April, which brought 281 Vietnamese children, many of them orphans, to Australia, and the evacuation of the Australian Embassy on 25 April. Whitlam decided that should Vietnamese refugees reach Australia by sea, they would be disembarked 'into custody'. He added that the Australian authorities ought to ensure 'that the boat is not made deliberately unseaworthy so that any Operation Phoenix or like types can be returned to the boat before other passengers are permitted to remain' ${ }^{8}$

The deliberations on 19 May and the paper prepared for Whitlam and the Ministers for Immigration and Foreign Affairs were informed by the assumption that

despite Australia's previous involvement and experience in refugee matters it had never been faced with the present kind of situation where 
there existed the possibility, if not the probability, of the unauthorised arrival of an unknown number of refugees by surface vessel...

and that

as the present problem is 'without precedent' it would be necessary for the Government in taking any decisions to give close attention to the possible consequences in relation to similar refugee situations which might arise in the future. ${ }^{9}$

How accurate was the assumption that there was no relevant historical precedent and that it was not possible to draw any useful historical analogies? By taking for granted that 'Australia's previous involvement and experience in refugee matters' had no bearing on the response to refugees arriving by boat, members of the interdepartmental working party drew a clear line between Australia's traditional approach to refugees and an approach to be taken in the case of 'unauthorised arrivals'. By drawing this line, they also excluded two contemporaneous issues from their discussions, which related to Australia's previous involvement in refugee matters: Australia's response to Vietnamese refugees in Vietnam and Australia's contribution to the debate about a proposed UN convention on political asylum.

Australia's previous experience in refugee matters also extended to the government's policy regarding the selection of refugees in Vietnam for resettlement in Australia. Under the direction of Whitlam, who was reported to have said that 'Vietnamese sob stories don't wring my withers', 10 the government had formulated a miserly response to those who had aligned themselves with the United States and its allies and who were desperate to leave South Vietnam before the fall of Saigon and the surrender of the South Vietnamese forces. By 30 April, only 78 Vietnamese refugees, excluding those who arrived on the two baby lifts, had been brought to Australia. These included a group of 34 nuns. Of the remainder, 40 were the spouses, children or fiancées of Australian citizens or permanent residents. Another 350 people had been approved for entry, but were unable to leave by the time the last Australian officials left Vietnam. ${ }^{11}$ When referring to public opinion sympathetic to Vietnamese refugees, the authors of the briefing paper were clearly informed by the debates of the previous six weeks, but they did not relate possible responses to boat arrivals to the previous response to refugees seeking admission to Australia from South Vietnam, Hong Kong or Singapore.

The Labor Government's response to refugees trying to leave Vietnam or being stranded elsewhere in South-East Asia had been widely criticised; the Opposition and sections of the media had argued that Australia could accommodate and should accept more Vietnamese refugees. The Australian approach contrasted starkly with that of the United States, which was taking in tens of thousands of 
people who had fled, or had been evacuated from, South Vietnam. The Whitlam Government's policy was, however, in line with that taken by its counterpart in New Zealand, where the National Party opposition had in fact tried to use the Australian response to shame the government into allowing more Vietnamese into the country, even though the Labor Government in Canberra was hardly more generous than the Labour Government in Wellington. ${ }^{12}$

The second omission concerns the Australian position in negotiations about the wording of relevant international instruments. Since the 1950s, various UN forums had been devoted to the issue of a convention that would give substance to Article 14 of the Universal Declaration of Human Rights. Australia had played a prominent role in those discussions. In 1967, Australia voted with the majority in the UN General Assembly for a Declaration on Territorial Asylum - safe in the knowledge that it did not thereby commit itself to responding to asylum-seekers in any particular way. Discussions about a proposed Convention on Territorial Asylum intensified in the first half of the 1970s. In fact, the government considered its response to the proposed convention at about the same time as it formulated its response to the anticipated arrival of refugees by sea. ${ }^{13}$ Representatives of the department centrally involved in the negotiations about the wording of the convention, the Attorney-General's Department, were not, however, invited to the meeting of 19 May.

In the version agreed to by Australia in 1954, the 1951 Refugee Convention applied only to people who had become refugees as a result of events happening in Europe before 1951. These temporal and geographical limitations were abolished by means of the 1967 Protocol to the 1951 Convention. Australia signed that protocol only in December 1973, less than 18 months before the meeting to draw up a contingency plan for the mass arrival of Vietnamese asylum-seekers. If Australia had not signed the protocol, it would have had no international legal obligations under the Refugee Convention to treat any Vietnamese 'unauthorised arrivals' other than as illegal immigrants.

Australia had good reasons not to sign the protocol until December 1973. They relate to the most intriguing absence from the discussions of 19 May 1975: the issue of Australia's previous response to asylum-seekers. Contrary to what those meeting that day assumed, the arrival of Vietnamese 'unauthorised arrivals' would not be unprecedented. Between 1963 and 1973, Australia had dealt with the unauthorised arrival of thousands of West Papuans who crossed into the Australian territory of Papua and New Guinea. Hundreds had been allowed to remain on temporary residence permits, while many others had been returned across the Indonesian border. ${ }^{14}$

In 1968, the Australian Government drew up detailed contingency plans because it feared that a large number of West Papuans would flee to Papua and New Guinea as a result of 'over-reaction by the Indonesian authorities' to nationalist 
demonstrations in West Papua planned for Indonesian Independence Day on 17 August. ${ }^{15}$ Similar contingency plans were developed the next year because it was feared that the so-called Act of Free Choice - when a select few West Papuans were given the opportunity to vote on the incorporation of West Papua into Indonesia (which by then had long been a fait accompli) - would be accompanied by violence and an influx of up to 3000 refugees. ${ }^{16}$ (None of these plans was ever activated because the number of refugees did not increase as dramatically as had been feared.)

On at least one occasion, West Papuan refugees had reached Australia itself: in 1969, a small group landed on one of the Torres Strait islands. They were threatened with deportation to Indonesia and persuaded to agree to their transfer to Papua and New Guinea to lodge applications for temporary residence permits in the Australian territory. These applications were later rejected and the applicants returned to Indonesia. ${ }^{17}$

West Papuans aside, Australia had had ample experience with people who sought Australia's protection after reaching Australia. They included, for example, diplomats, crew from Eastern European ships and sportspeople. Since 1956, Australia had a policy that guided its response to requests for asylum. ${ }^{18}$ Since 1962, it had a similar policy with respect to asylum-seekers from the western half of New Guinea who sought Australia's protection in the Territory of Papua and New Guinea. ${ }^{19}$

Why did those meeting on 19 May refer neither to what appeared-not merely with the benefit of hindsight - to be highly relevant earlier developments nor to any precedents? Vietnamese selected in Saigon in April 1975 were refugees much like Hungarians selected in Austrian refugee camps in 1956 and 1957. They were admitted to Australia as immigrants and had to meet selection criteria that were akin to those in place for other immigrants. For Vietnamese refugees in April 1975, these criteria were particularly restrictive, whereas at the same time, the normal immigration selection criteria had been relaxed for other refugees, such as Chileans who had fled to neighbouring South American countries in the wake of the overthrow of the Allende Government. ${ }^{20}$ Irrespective of that difference, however, the admission of both groups of refugees was meant to be the outcome of a selection process, the criteria of which were informed by Australia's broader immigration policy, rather than determined by a distinct refugee policy - one divorced from immigration policy. In fact, the Whitlam Government had been less inclined than its conservative predecessors to make special allowances for refugees wanting to settle in Australia. In July 1974, several voluntary agencies concerned with the resettlement of refugees had made a joint submission to the Minister for Labour and Immigration in which they noted 'with great concern...that during the last eighteen months or 
so the Government has very largely discarded the application of compassionate and humanitarian considerations to refugee and near-refugee cases' ${ }^{21}$

Refugees selected for resettlement made up merely one of many categories of applicants selected overseas for immigration to Australia. Those arriving uninvited did not come in response to Australia's needs and would not go through a selection process that resembled that in place for ordinary immigrants; they were therefore not comparable with overseas applicants, including refugees, who wanted to migrate to Australia. The fact that the minutes of the meeting of 19 May refer to those selected offshore for resettlement and those thought to be on their way to Australia by boat as refugees easily obscures the fact that the former were not conceptualised in the same way as the latter.

The absence of references to the discussions about the UN Declaration on Territorial Asylum, and to the precise nature of Australia's international legal obligations, is likely to have been a result of the fact that the Attorney-General's Department was not invited to the interdepartmental meeting. International instruments seemed to matter mainly because, faced with the realistic prospect of scores of asylum-seekers reaching the country by boat, Australia wanted to be seen to abide by them - as long as they did not get in the way of Australia's prerogative to decide whether or not a non-citizen was allowed to enter the country.

In May 1975, Papua New Guinea's independence was still almost four months away. Papua New Guinea was, however, being eased towards nationhood. On 1 December 1973, the former Australian colony had become self-governing; few exceptions aside, the government of Michael Somare was in charge of the country's domestic affairs. The Office of the Administrator had been abolished and its previous incumbent had become Australia's first High Commissioner to Papua New Guinea. The government in Port Moresby, rather than that in Canberra, made decisions about the fate of West Papuans entering Papua New Guinea to seek its protection. Australians were now able to regard the issue of West Papuans seeking Australia's protection as a unique problem that belonged to an ostensibly closed chapter in Australia's history. Furthermore, by May 1975, Australian colonial rule in Papua New Guinea was already being treated as if it had been an episode of comparatively minor significance. Not only was the chapter considered closed even before Papua New Guinea became independent, it was already being omitted from the histories Australians remembered and told about their nation.

While the arrival of refugees on Australia's shores was not unprecedented, the manner in which those meeting on 19 May 1975 could deal with such an event certainly was. The government officials exploring various options would have been conscious of certain well-established procedures: since 1945, decisions about the admission to Australia of non-citizens were the prerogative of the 
Department of Immigration and its minister; in cases in which prospective residents applied for political asylum, the Immigration Department liaised with the Department of Foreign Affairs. Both departments also sought advice from the Australian Security Intelligence Organisation (ASIO). In some instances, the two ministers would have to take a case to cabinet. Cabinet would usually make a decision on the basis of a submission prepared by the relevant department(s). In relation to Vietnamese refugees, however, such procedures were no longer followed. Nancy Viviani and Joanna Lawe-Davies concluded that 'Australian refugee policy in 1975 was Whitlam policy and his alone' ${ }^{22}$ and that Whitlam's 'Cabinet and Caucus colleagues [and] the departments most concerned...played almost no role in policy-making, and there was little sense of continuity with previous policies and practices on refugees' ${ }^{23}$

In April and May 1975, the Department of Labour and Immigration was involved in revising Australia's refugee policy. At the Labor Party's Terrigal conference in February 1975, the platform concerning immigration policy had been amended: a Labor government was now required to allow for '[s]ympathetic consideration of people who for political and other reasons would face danger to life and liberty upon return to their country of origin'. ${ }^{24}$ Those involved in formulating the new policy, however, including the Minister for Immigration, Clyde Cameron, had to exclude from any revised formula Vietnamese and Cambodians, 'where decisions of acceptability have been made by the Prime Minister' ${ }^{25}$

In 1975, the government officials discussing contingency plans for the arrival of Vietnamese asylum-seekers talked about an unprecedented situation. Their deliberations were, however, also indebted to a particular understanding of Australian history. The reference to the precedent 'which would not go unremarked by people in a number of countries to the north of Australia' was informed by long-held fears about Australia's vulnerability to being invaded by people living in countries to its north. While those attending the meeting of 19 May 1975 did not make any references to specific incidents in the past, their ideas were nevertheless informed by particular memories: in this case, memories of deep-seated anxieties about an Asian invasion. These anxieties had been partly responsible for the development of the White Australia Policy (including the notorious Immigration Restriction Act 1901) and for the fact that that policy had remained in place until 1973, and had continued to be a powerful force well beyond 1973. It is not surprising that when sizeable numbers of Vietnamese refugees did arrive from late 1976, the most prominent 'historical' references were to a human tide swamping Australia. Earlier instances in which Australia had to deal with asylum-seekers did not seem to be relevant because they had not been interpreted through the prism of that fear.

Whitlam's decision that any Vietnamese asylum-seekers were to be disembarked into custody was also informed by particular memories. Much like his Labour 
Party counterpart in New Zealand, Bill Rowling, who was equally reluctant to commit his government to admitting a sizeable number of refugees from Vietnam, ${ }^{26}$ Whitlam had opposed Australia's involvement in the Vietnam War and had been a critic of the American execution of that war. He assumed that at least some of those fleeing Vietnam had been the agents of highly dubious South Vietnamese and US policies (such as the notorious Operation Phoenix) and were now escaping retribution at the hands of the victors.

There was no debate - in Parliament or in the media - about the government's contingency plans of May 1975. The plans, and Whitlam's decision about what to do in the eventuality that a boat with Vietnamese refugees arrived in Australia, were never made public. There was, of course, public speculation about what Australia might do in such an eventuality. Such speculation was particularly rife in May 1975, after reports of the imminent departure of refugees for Australia (see above). Those engaged in such speculation were, however, unaware of the fact that the government carefully considered its options and decided on a policy.

By the time the first boat with Vietnamese refugees arrived, however, the policy that had been developed in May 1975 no longer applied. On 21 April 1976, in the course of the 1975-76 Senate inquiry into Australia's response to refugees from Vietnam, an Immigration Department official commented on the possibility of asylum-seekers arriving: 'We are well aware of the likelihood of future situations in which we may be the country of first asylum and are developing processes that will look after the situation of that kind in the future.' The development of such processes was apparently necessary because 'we do lack a policy for that sort of situation' ${ }^{27}$

The official did not tell the committee that less than 12 months earlier, his department had been involved in the development of such a policy. Neither did he refer to events that demonstrated that the policy of May 1975 did not apply to asylum-seekers generally. In the second half of 1975, Australia had accommodated a substantial number of refugees arriving from East Timor by boat and using Australia as a country of first asylum without following the policy agreed to with respect to Vietnamese boat arrivals in May 1975. On 8 December 1975, another interdepartmental meeting involving officers from all departments represented at the meeting of 19 May 1975, as well as from Treasury, drew up contingency plans for the arrival of East Timorese refugees by boat. The December meeting considered the guidelines developed in May but found that they

were not strictly relevant to the present situation, and the precedent which should be followed was that established in September of this year, when some hundreds of persons arrived in Darwin from Portuguese Timor and were permitted to land under temporary entry permits. ${ }^{28}$ 
The minutes of the December meeting do not spell out why the existing policy was no longer relevant. It seems safe to assume that the bureaucrats convening in December were aware that the policy developed in May represented Whitlam's personal views about Vietnamese refugees (rather than refugees generally), that these views were at odds with those held by other members of his government and that they were diametrically opposed to those of Malcolm Fraser, who had succeeded him as Prime Minister on 11 November 1975.

The immigration official appearing before the Senate inquiry in April 1976 was not referring to a specific scenario when he mentioned the likelihood of Australia being a country of first asylum. Given that the government was not aware of any particular group of refugees heading towards Australia at the time, it is unlikely that he had a specific scenario in mind. Only a week after he had given evidence, however, the event that had been anxiously anticipated in May 1975 finally eventuated. On 27 April 1976, the first boat carrying Vietnamese refugees arrived in Darwin. Its arrival came as a surprise, but caused barely a ripple at the time. As Viviani and Lawe-Davies write, '[T]hese first arrivals stirred no recollection of earlier anxieties ${ }^{29}$ - the government, the Immigration Department, journalists and members of the public seemed not to be concerned about the precedent that was set when the first five 'unauthorised arrivals' were allowed to land, were given temporary residence permits a day after their arrival and soon afterwards were granted permanent residence. ${ }^{30}$ In fact, when the government identified the need for an extra customs patrol boat in northern Australian waters only a week after the arrival of the first Vietnamese 'boat people', it did so because it was concerned to combat drug smuggling rather than to detect vessels carrying refugees. ${ }^{31}$

\section{'Boat people' (II)}

In my second case, I am concerned not so much with the deliberations of policy makers as with the debates taking place after the policy in question has been announced and with what this indicates about the uses of history in political debate. In May 2006, the Liberal-National Coalition Government introduced the Migration Amendment (Designated Unauthorised Arrivals) Bill into Parliament. ${ }^{32}$ If passed, it would have excised the Australian coastline from the migration zone and thereby prevented asylum-seekers who had reached the mainland by boat from engaging Australia's protection obligations and having their request for a protection visa heard in Australia. Instead, their applications for a visa would have been processed offshore, in Nauru or Papua New Guinea, in the same way in which the applications of asylum-seekers who had reached Australian islands excised from the migration zone in the wake of the Tampa crisis had been processed offshore. The bill was drafted in response to vociferous Indonesian protests against the granting of protection visas to a small group of West Papuan refugees who had landed on the Queensland coast in January 2006; ostensibly 
it was to rectify the alleged anomaly that asylum-seekers were treated differently depending on whether or not they had been able to reach the mainland.

When the government introduced the proposed legislation, it assumed that it would be passed much like most other amendments to the Migration Act since 1999, the more so as the government commanded a majority in both houses of Parliament. In the end, however, the government withdrew the legislation before it could be debated in the Senate because it looked certain to be defeated with the help of two members of the Coalition and a minor party senator who usually voted with the Coalition. ${ }^{33}$ The proposed legislation was, however, debated at length in the House of Representatives. That debate, on 9 and 10 August 2006, ranks as one of the most memorable parliamentary events during John Howard's 11-year reign as prime minister because of the impassioned speeches delivered by four Liberal MPs who condemned the government's bill, and because for once the Labor opposition rejected outright a measure purportedly designed to protect Australia's borders.

In the four-month public debate over the bill, ${ }^{34}$ the past loomed large. The specific historical contexts, however, for the introduction of legislation designed to extend the reach of the extraterritorial processing regime for asylum-seekers and to keep West Papuan asylum-seekers out of Australia barely featured. Australians following the debate and relying on a combination of respectable print and electronic media were likely to assume that the 43 West Papuans who arrived in early 2006 were the first West Papuan asylum-seekers Australia had to deal with, and the first Indonesian nationals who were allowed to remain in Australia because they could convincingly claim that they would be persecuted on their return to Indonesia.

The fact that West Papuan refugees had sought Australia's protection since 1962, the fact that for many years Australia had tried to avoid granting protection visas to East Timorese refugees (while nevertheless permitting them to remain in Australia on temporary visas) in the interest of its relationship with Indonesia ${ }^{35}$ and the fact that small numbers of Indonesian nationals had been granted protection or humanitarian visas under Immigration Minister, Philip Ruddock, and his successor, Amanda Vanstone, were all but omitted from the debate.

The fact that Australia had not signed the 1967 protocol, which made the provisions of the 1951 Convention universal, until after Papua New Guinea became self-governing in December 1973, was also not mentioned. The informed public could have been forgiven for assuming that Australia had been constrained by its international legal obligations with regard to asylum-seekers since the establishment of the Office of the UN High Commissioner for Refugees and the drafting of the 1951 Refugee Convention.

My intention here is not to comprehensively analyse the controversy over the 2006 migration amendment bill. Rather, I focus on the debate in Parliament, 
which in many ways was both the apex and the conclusion of the larger public debate. References to the past featured prominently in the nine-and-a-half hour exchange in the House of Representatives, during which 31 members made a contribution. Not surprisingly, most historical references were to the application of laws introduced since 2001 to underpin the government's 'Pacific Solution', as the proposed legislation would have extended the application of that policy. There were, however, only two references to the widely held fear (if not to say hysteria) that had allowed the government to introduce the Pacific Solution in the first place, and then to benefit from its introduction at the 2001 federal election. ${ }^{36}$ Another obvious history that was frequently invoked was that of legislation introduced - with bipartisan support and on the instigation of several Liberal backbenchers - in 2005 to exempt children from Australia's policy of mandatory detention for unauthorised boat arrivals. ${ }^{37}$ One other relevant piece of legislation was explicitly referred to: the introduction of mandatory detention by the Labor Government in 1992. ${ }^{38}$

Only two mentions were made of previous instances when refugees arrived by boat in Australia. Renegade Liberal backbencher Petro Georgiou began his speech with such a reference: 'Thirty years ago, after a long and hazardous journey, a small group of Vietnamese refugees landed on a remote beach in Northern Australia. ${ }^{39}$ Labor's Jill Hall recounted a potted history of Australian responses to refugees, starting with the convicts ('The first people of English descent who came to Australia were refugees from the prison system in the UK'), and also mentioning '95,000 Vietnamese refugees' accommodated between 1975 and 1985 at 'a time when people came in boats to Australia and Australia recognised their needs, embraced them and took them into our society' ${ }^{40}$ Hall did not clarify that of those 95 000, only about 2 per cent actually came to Australia by boat. In 1996, Viviani commented on this issue:

Even though this historic period of upheaval in Southeast Asia and its effects are within living memory of most Australians, it is extraordinary how the interpretations of this experience have diverged from the clear facts... [T] he fact that just over 2000 boat people arrived on the northern shores of Australia from 1976 to 1989 has been wildly distorted in the media on every occasion that a boat arrives. ${ }^{41}$

Only Labor's Duncan Kerr drew attention to the fact that West Papuans had been fleeing their country since Indonesia assumed control of it (although he did not say when that had happened). ${ }^{42}$ He also mentioned that many fled to Papua New Guinea (but he did not mention that this also occurred when Papua New Guinea was under Australian control, that the Australian Government's response was informed by its desire to appease Indonesia and that Australian officials routinely sent refugees back to Indonesia). Kerr's discussion of the 
historical context took up no more than 10 minutes (or about 2.5 per cent of the parliamentary debate).

Other members briefly referred to the 1951 Refugee Convention. None mentioned that until 1973 that convention had been, strictly speaking, irrelevant for Australia's response to West Papuan asylum-seekers. Labor's Chris Bowen said:

In 1951 the United Nations convention for the protection of refugees came into force. The world realised the mistakes of the 1930s, when many Western nations turned their backs on Jews fleeing persecution in Germany. Collectively, we said, 'Never again.' 43

Bowen was wrong about the date. He was also mistaken about why and how the convention had been drafted. And who was included in his first-person plural? Those who said 'never again' in 1949 or 1951 were a minority -in the context of global politics and in the context of Australian politics. ${ }^{44}$

While the speeches by Hall, Kerr and Bowen are easy targets for historically informed criticism, they nevertheless stand out on account of the interest the three Labor MPs showed in the broader historical context of the proposed legislation. In public debates about asylum-seeker policy, statements that make comparatively specific reference to historical detail have been the exception. Besides, the speeches were marginal: they were not quoted in major newspapers or on the evening news.

Unspecific references to traditional Australian generosity and hospitality were far more central to the debate itself and to how it was reported than references to relevant historical contexts and precedents. 'Can I say that Australia's generosity towards refugees is outstanding,' the Liberal Party's Don Randall said, adding elsewhere the hyperbolic statement, 'Australia is incredibly overgenerous. ${ }^{45}$ Other Coalition members repeatedly referred to Australia's record on resettling refugees, of which 'we' could be proud. ${ }^{46}$ In the debate's closing speech, Andrew Robb, the Parliamentary Secretary to the Minister for Immigration and Multicultural Affairs, noted Australia's 'very proud record over 55 years' ${ }^{47}$

Those opposed to the legislation also talked about Australia's traditional generosity, only to claim that this 'proud record' would be undermined by the proposed legislation. Labor's Ann Corcoran said: 'I am embarrassed and ashamed to see our once proud reputation for upholding principles of human rights further sullied by this amoral government.' 48 Jill Hall also thought that 'Australia's history in relation to refugees has been somewhat sullied over the last few years' ${ }^{49}$ Their party colleague Carmen Lawrence accused the Prime Minister of 'having trashed Australian standards of compassion and decency'. ${ }^{50}$ Georgiou made a similar point: 
The ancient and universal tradition of providing sanctuary to those in danger is part of our refugee regime in Australia today, and it is demonstrated by the community at large when Australians respond generously to the suffering of others, both at home and abroad. The [bill] does not reflect this tradition. It does not uphold the deeply held Australian values of giving people a fair go, and of decency and compassion. ${ }^{51}$

Bruce Baird, another Liberal dissident, claimed that an Australia preventing West Papuan refugees from applying for a protection visa is not the Australia that we know and respect. Australia is a generous nation. It is one that has shown enormous compassion to people in need and on an ongoing basis. ${ }^{252}$

Australia's current Prime Minister, Kevin Rudd, considers compassion to be one of five values 'which might underpin a vision for the nation's future'. ${ }^{53}$ His rhetoric about compassion as an essential value in Australia's past and for Australia's future is similar to that of two of his most recent predecessors, former Labor leader Mark Latham and former Prime Minister John Howard. ${ }^{54}$ The latter employed references to Australia's and Australians' compassion also to reject criticism of his government's policies - in particular, its asylum-seeker policies. In late August 2001, while the Tampa was drifting in waters near Christmas Island, Howard told Fran Kelly of ABC TV's 7.30 Report: 'We are a decent generous, compassionate humanitarian country, but we also have an absolute right to decide who comes to this country.' ${ }^{\prime 55}$

Howard used the attributes 'decent', 'generous' and 'compassionate' to describe an Australia past and present. He and other members of his government were always ready to provide evidence of Australia's generosity, such as the fact that, in relation to its population, Australia had resettled more refugees since the end of World War II than any other nation except Israel.

The assertion that Australia and Australians have traditionally been generous and compassionate has become something of a background chorus accompanying debates about public policy, particularly in the area of immigration and refugee policy. The level of that noise increases if Australia is condemned in international forums, be it in relation to the government's Aboriginal policies or in relation to its asylum-seeker policies, almost as if repeated appeals to Australia's and Australians' intrinsic generosity can drown out such criticism. The noise itself, however, is not triggered by external criticism. This chorus needs to be seen in the context of the rhetoric about aspiration, about the desirability of living in a shareholder society and about citizens' responsibility to help themselves before society comes to their assistance. Australians want to be reassured that, after all (and contrary to much available evidence), they are by nature a decent, generous, compassionate and hospitable people. The chorus is also related to the notion 
that compassion is accorded to people who deserve it, rather than that human beings are entitled to respect and assistance.

\section{Conclusion}

It is important to draw attention to relevant histories that are ignored. That is particularly true for narratives about specific historical responsibilities - towards South Vietnamese refugees or towards West Papuans, for example. It would be a mistake, however, to leave it at that, because any triumphant finger-pointing could easily get in the way of an exploration of why certain narratives do not have sufficient currency and how policy makers and others contributing to public debate really use the past; to claim that the debate about asylum-seeker policies has been marked by the absence of informed references to the past is not to say that it has been devoid of any historical connotations.

It is tempting to think of the past as a repository open for inspection. According to such an understanding, those failing to draw on the past simply do not inspect the repository available to them. It is not so much the past that policy makers draw on, however, as histories and memories. It is not the past itself that is available to them, but a limited number of accounts of that past. The question to ask is not only why did the officials pondering the imminent arrival of Vietnamese 'boat people' ignore relevant historical precedents and other relevant previous instances of policy making, but why don't Australian social memories of Australia's response to refugees feature the arrivals of West Papuan asylum-seekers in the Australian territory of Papua and New Guinea, and why do Australian refugee policies tend to be remembered as continuations of or deviations from a long-established tradition of compassionate and generous approaches to refugees?

References to relevant historical precedents did not inform the discussions in 1975 about what to do if Vietnamese refugees were to seek asylum in Australia, or the debate in 2006 about the merits of the government's response to the arrival of 43 West Papuan asylum-seekers. Those formulating policy in 1975, however, and those debating policy in 2006 relied on their particular understanding of Australia's past. In 1975, policy makers were concerned not to set a precedent that would realise historical fears of an invasion by 'people in a number of countries to the north of Australia'. They did not attempt to draw on the past to identify the best policy solution; rather, the past 'encroached' on them. ${ }^{56}$ In 2006, many of those debating the proposed legislation invoked the image of a traditionally compassionate Australia - again, not in order to identify the best possible policy solution but as a spontaneous response to anxieties about Australians' apparent tendency to be self-interested.

Leaving aside the threat of a Japanese attack during World War II, fears of an Asian invasion have been as unjustified as the idea that Australia has a better 
humanitarian record and is more compassionate than other comparable nations. That does not make those fears, and ideas about compassion as a quintessentially Australian value, less real; it demonstrates that those formulating and debating public policy do not look back at the past, but draw on histories and memories of that past.

\section{Acknowledgments}

This chapter was written in response to an invitation to present at the Governing by Looking Back conference in December 2007 at The Australian National University. I thank Tim Rowse and Paul 't Hart for inviting me to the conference, and Gwenda Tavan for her helpful comments on an earlier version of the paper.

\section{Endnotes}

1 Terry, Peter 1975, 'Fleeing South Vietnamese ships may risk voyage to Australia: federal govt takes tough stand on uninvited refugees', Australian, 6 May 1975.

2 Viviani, Nancy 1980, Australian Government Policy on the Entry of Vietnamese Refugees in 1975, Centre for the Study of Australian-Asian Relations, Griffith University, Brisbane, pp. 14, 21 n. 71.

3 Willesee to Prime Minister, 6 May 1975, National Archives of Australia [hereafter NAA], A1209, $1975 / 1156$.

4 Vietnamese refugees in Singapore, Draft, n.d., attachment to K. H. Rogers to Gilchrist and others, 9 May 1975, NAA, A1838, 1634/70/2 part 1.

5 D. McElligott and R. Tynan to Prime Minister, 20 May 1975, NAA, A1209, 1975/1333.

6 Contingency planning: unauthorised arrival of Vietnamese, n.d. [20 May 1975], NAA, A1209, $1975 / 1333$.

7 Ibid.

8 Quoted in K. H. Rogers to Feakes, 3 July 1975, NAA, A1838, 1634/70/2 part 3.

9 Department of Labour and Immigration, Summary of discussions at interdepartmental working party meeting, Canberra, 19 May 1975, n.d. [ca 26 May 1975], NAA, A1209, 1975/1157, p. 4.

10 Quoted in Viviani, Australian Government Policy on the Entry of Vietnamese Refugees in 1975, p. 11.

11 Foreign Affairs to all posts, 6 May 1975, NAA, A1209, 1975/1144. See also Community Affairs Branch, Vietnamese refugees, 13 August 1975, NAA, A1209, 1976/242 part 1. Some of those approved for immigration to Australia were subsequently evacuated by the US military.

12 New Zealand Parliamentary Debates [hereafter NZPD], vol. 396, 3 April 1974, p. 170; NZPD, vol. 396, 11 April 1975, p. 411. By 3 September 1975, New Zealand had admitted a mere 99 Vietnamese (NZPD, vol. 401, 3 September 1975, p. 4091).

13 See correspondence in NAA, A1838, 938/43 part 2.

14 Neumann, Klaus 2004, Refuge Australia: Australia's humanitarian record, UNSW Press, Sydney, ch. 5 .

15 D. O. Hay to Secretary, Department of External Territories, 28 June 1968, NAA, A452, 1968/2812. The part of Indonesia commonly known as West Papua was then called West Irian.

16 Department of the Administrator, Border contingency plan, 3 June 1969, NAA, A1838, TS689/2/1.

17 Neumann, Klaus 2007, 'Been there, done that?', in Dean Lusher and Nick Haslam (eds), Yearning to Breathe Free: Seeking asylum in Australia, Federation Press, Annandale, pp. 21-34.

18 Cabinet decision no. 487, 16 October 1956, NAA, A4926, 398. See also Neumann, Refuge Australia, ch. 4 .

19 Cabinet decision no. 375, 6 August 1962, NAA, A5819, vol. 8/agendum 330.

20 Peter Wilenski, Draft submission to Minister, May 1975, NAA, A446, 1974/77554.

21 Australian Council of Churches (Resettlement Department) and others to C. R. Cameron, 31 July 1974, NAA, A446, 1974/95371. 
22 Viviani, Nancy and Lawe-Davies, Joanna 1980, Australian Government Policy on the Entry of Vietnamese Refugees 1976 to 1978, Centre for the Study of Australian-Asian Relations, Griffith University, Brisbane, p. 1.

23 Viviani, Australian Government Policy on the Entry of Vietnamese Refugees in 1975, p. 15.

24 Quoted in Dempsey to Minister, 2 April 1975, NAA, A446, 1974/77554.

25 R. U. Metcalfe to Minister, 4 July 1975, NAA, A446, 1974/77554.

26 Rabel, Roberto 2005, New Zealand and the Vietnam War: Politics and diplomacy, Auckland University Press, Auckland, ch. 13; Gallienne, Robin 1991, The Whole Thing Was Orchestrated: New Zealand's response to the Indo-Chinese refugees exodus 1975-1985, Centre for Asian Studies, University of Auckland, Auckland, ch. 3.

27 John Selwyn Dempsey in Commonwealth of Australia 1976, Standing Committee on Foreign Affairs and Defence (Reference: South Vietnamese Refugees), Senate, Government Printer, Canberra, vol. 2, pp. 858,881

28 K. H. Rogers to Minister, 10 December 1975, NAA, A1838, 1634/69/2 part 2.

29 Viviani and Lawe-Davies, Australian Government Policy on the Entry of Vietnamese Refugees 1976 to 1978, p. 4.

30 In the most prominent press report, in Darwin's Northern Territory News ('Vietnamese refugees can stay', 28 April 1976), no mention was made of concerns about further boat arrivals; Australia's major newspapers either did not report the arrival or mentioned it in only a brief note.

31 'Extra patrol boat in north to combat drug smuggling', Northern Territory News, 4 May 1976.

32 Harris Rimmer, Sue 2006, 'Migration Amendment (Designated Unauthorised Arrivals) Bill', Bills Digest, Parliamentary Library, 138 (22 May 2006), <http://parlinfo.aph.gov.au/parlInfo/ search/display/display.w3p;query=BillId_Phrase\%3Ar2559\%20Dataset\%3Abillsdgs;rec=0>

33 National Party Senator Barnaby Joyce, Liberal Party Senator Judith Troeth and Family First Senator Steve Fielding.

34 The debate lasted from when the bill was first foreshadowed by Immigration Minister Vanstone on 13 April 2006 until its withdrawal by the Prime Minister on 14 August 2006. Vanstone, Amanda 2006, Strengthen border control measures for unauthorised boat arrivals, Media release, 13 April 2006, <http://pandora.nla.gov.au/pan/32192/20060606-0000/sievx.com/articles/westpapua/ 20060413AmandaVanstone.html>; Howard, John 2006, Transcript of press conference, Parliament House, Canberra, 14 August 2006,

<http://pandora.nla.gov.au/pan/10052/20060921-0000/www.pm.gov.au/news/interviews/Interview2073.html>

35 Piotrowicz, Ryszard 1996, 'Refugee status and multiple nationality in the Indonesian archipelago: is there a Timor gap?', International Journal of Refugee Law, vol. 8, no. 3, pp. 319-46; Mathew, Penelope 1999, 'Lest we forget: Australia's policy on East Timorese asylum seekers', International Journal of Refugee Law, vol. 11, no. 1, pp. 7-59.

36 Sharon Grierson from the Labor Party claimed that 'this legislation is just a continuation of that same inflammatory hysteria' (witnessed during the Tampa affair) ( $C P D$, Representatives, vol. 283, 9 August 2006, p. 137). Labor's Bob McMullan also suggested that the legislation was 'part of a long history in Australia of the easy appeal to fear' (CPD, Representatives, vol. 283, 10 August 2006, p. 8).

37 Migration Amendment (Detention Arrangements) Act 2005.

38 Don Randall, $C P D$, Representatives, vol. 283, 9 August 2006, p. 25.

$39 C P D$, Representatives, vol. 283, 9 August 2006, p. 40.

40 CPD, Representatives, vol. 283, 10 August 2006, p. 39.

41 Viviani, Nancy 1996, The Indochinese in Australia, 1975-1995: From burnt boats to barbecues, Oxford University Press, Melbourne, pp. 10-11.

42 CPD, Representatives, vol. 283, 9 August 2006, pp. 119-20. Kerr's office had produced a substantial background paper on the issue of West Papuan asylum-seekers (Sophia Rihani, Human rights abuse in Papua: implications for Australian foreign policy [15 May 2006]).

43 CPD, Representatives, vol. 283, 10 August 2006, p. 15.

44 Labor's Shadow Minister for Immigration, Tony Burke, made a similar statement when he claimed that the 1951 convention 'was put in place because Jewish people fled Germany and no country would take them. The rest of the world swore they would never let this happen again.' $C P D$, Representatives, vol. 283, 9 August 2006, p. 20. Labor's Anthony Albanese argued in a similar vein: 'Why was the refugee convention developed by the United Nations in the post-World War II period? It was because 


\section{Does History Matter?}

of the experience of Jewish citizens fleeing Nazi Germany and the other fascist persecutors in Europe. These Jewish refugees were pushed back offshore in their boats, in many cases sent back to their deaths. The world said: "Never again."' CPD, Representatives, vol. 283, 10 August 2006, p. 35; emphasis added. 45 CPD, Representatives, vol. 283, 9 August 2006, pp. 27, 29. Similarly, Andrew Robb claimed: 'As a country, we are strong and fair on these matters and generous to a fault.' $C P D$, Representatives, vol. 283, 10 August 2006, p. 44.

46 For example, the Liberal Party's Peter Slipper (CPD, Representatives, vol. 283, 9 August 2006, p. 117 ) and the Liberal Party's Alan Cadman (CPD, Representatives, vol. 283, 10 August 2006, p. 11).

$47 C P D$, Representatives, vol. 283, 10 August 2006, p. 39.

48 Ann Corcoran, CPD, Representatives, vol. 283, 9 August 2006, p. 40. Similarly, Labor's Maria Vamvakinou expressed her fear that Australia's reputation would be compromised ( $C P D$, Representatives, vol. 283, 9 August 2006, p. 114). Labor's Sharon Grierson said that the Australian nation 'is capable of generosity, compassion, integrity and international leadership' ( $C P D$, Representatives, vol. 283, 9 August 2006, p. 140).

49 CPD, Representatives, vol. 283, 10 August 2006, p. 39.

$50 C P D$, Representatives, vol. 283, 9 August 2006, p. 129.

51 Ibid., p. 44.

52 Ibid., p. 126.

53 CPD, Representatives, vol. 271, 30 May 2005, p. 86. Rudd's other values are security, competition, fairness and sustainability. In his first speech as Leader of the Opposition, he nominated six values: liberty, security, opportunity, equity, sustainability and compassion (CPD, Representatives, vol. 287, 5 December 2006, p. 41).

54 Mark Latham cited four Australian values: work, reward for effort, aspiration and compassion (CPD, Representatives, vol. 259, 4 December 2003, p. 23857). 'This is a free, stable, prosperous and compassionate nation,' Howard said - for example, in his New Year message at the end of 2002 (Howard, John 2002, Media release, 31 December 2002, <http://pandora.nla.gov.au/pan/10052/20080108-1314/ livetest.pm.gov.au/media/Release/2002/media_release2055.html >).

55 Howard, John 2001, Transcript of television interview with Fran Kelly, 7:30 Report, ABC TV, 27 August 2001, <http://pandora.nla.gov.au/pan/10052/20080108-1314/ livetest.pm.gov.au/media/Interview/2001/interview1188.html>

56 Brändström, Annika, Bynander, Fredrik and 't Hart, Paul 2004, 'Governing by looking back: historical analogies and crisis management', Public Administration, vol. 82, no. 1, p. 194. 